\title{
The implementation of renewable energy systems, as a way to improve energy efficiency in residential buildings
}

ABSTRACT: The constant increase in the popularity of renewable energy systems allows residential building users to apply solutions leading to the diversification of the energy supply. The use of RES systems in residential buildings not only contributes to a higher level of environmental care, but also significantly and measurably improves the energy efficiency of the facility. Using hybrid systems allows the supply to be reduced or eliminated from conventional energy sources. The article presents common layouts of renewable energy systems, which are successfully used in residential buildings. It also shows the impact of such systems on the amount of savings achieved in the use of energy from external or conventional sources. In residential buildings, the possibility of energy generation in the form of electricity and heat is dependent on many factors that determine the type and size of the systems used to obtain energy from renewable sources. We should assume the further and continuous development of RES, which will increase the share of electricity and heat produced in households. Technological development, decreasing prices of equipment and components used for the installation of green electricity generation systems will be a conducive factor for increasing the popularity of RES systems, not only for residential buildings but also for other types of buildings. The article also points out the economic aspect of the RES systems application. It presents the po-

Corresponding Author: Sławomir Sowa; e-mail: Slawomir@sowa.poznan.pl

1 Poznan University of Technology, Electric Power Engineering, Faculty of Electrical Engineering, Poznań, Poland; ORCID iD: 0000-0001-9030-7185; e-mail: Slawomir@sowa.poznan.pl

2020. The Author(s). This is an open-access article distributed under the terms of the Creative Commons Attribution-ShareAlike International License (CC BY-SA 4.0, http://creativecommons.org/licenses/by-sa/4.0/), which permits use, distribution, and reproduction in any medium, provided that the Article is properly cited. 
sitive impact of RES installations on the environment and estimates the average time of financial reimbursement. The economic analysis concerns individual systems of renewable energy systems used in residential buildings.

KEYwORDS: power market, dispersed energy sources, renewable energy sources

\section{Renewable energy systems in residential buildings}

Over the last decade we have observed a steady increase in the share of renewable energy in the final value of generated energy. This trend is observed all over the world. The installed capacity of renewable energy sources increased from 1,058 GW in 2007 to 2,179 GW in 2017 (IRENA 2018). The smallest power increase can be observed in hydropower and the largest in systems using solar radiation.

Figure 1 shows the installed capacity of individual RES systems worldwide from 2008 to 2017 (IRENA 2018). In Poland, at the end of 2019, the installed capacity in RES systems was 9,106.258 MW. The vast majority of energy generated from renewable sources comes directly from large industrial plants, which have an increasing share in the national energy system. Renewable energy systems used in residential facilities have a long-standing tradition. Although the principle of obtaining free, green energy has remained practically unchanged, technological development, increased social awareness and greater care for the natural environment have resulted in a continuous increase in the number of RES installations. The idea of obtaining energy from renewable sources itself has more and more supporters. In Poland, as of December 31, 2019, there were over 155 thousand micro installations with a total installed capacity of $999.986 \mathrm{MW}$. A comparison of the quantity and power of micro installations by different RES systems is presented in Table 1 . The year 2019 was a peak year in terms of the increase in the number of micro-installations and the capacity installed in them. It is estimated that at the end of 2019, there were already over 155,000 micro installations with a total capacity of $1 \mathrm{GW}$ operating in our country. This means a three-fold increase compared to the previous year 2018. This is mainly due to government programs that partially reimburse the expenses incurred for the purchase and assembly of the installation. Having a RES installation and the possibility to reduce conventional energy consumption is most often determined by financial aspects (Siedlecka and Grąszko 2016).

Among the most popular systems are those obtaining energy from solar radiation. The overall accessibility of solar energy and relatively low costs of installations generating energy converted from solar radiation are the factors determining the great popularity of these systems. Currently, the most frequently used RES systems in the construction industry are PV photovoltaic installations, heat pumps, solar collectors and wind turbines. These systems are listed in the order of their current popularity, which is different for different regions and places in the world. Their popularity has also changed over the years, mainly due to developing technology, which increa- 
TABLE 1. The capacity installed in Poland, in individual micro RES installations

TABela 1. Moc zainstalowana w Polsce, w poszczególnych mikroinstalacjach OZE

\begin{tabular}{|l|r|r|}
\hline \multicolumn{1}{|c|}{ Type of micro installation } & $\begin{array}{c}\text { Number of micro installations } \\
{[\mathrm{pcs}]}\end{array}$ & $\begin{array}{c}\text { Total installed capacity } \\
{[\mathrm{MW}]}\end{array}$ \\
\hline Using solar radiation & 155,189 & 990.506 \\
\hline Water & 289 & 8.258 \\
\hline Using agricultural biogas & 25 & 0.665 \\
\hline Wind & 73 & 0.384 \\
\hline Using biomass & 5 & 0.173 \\
\hline Total & 155,626 & 999.986 \\
\hline
\end{tabular}

Source: URE 2020.

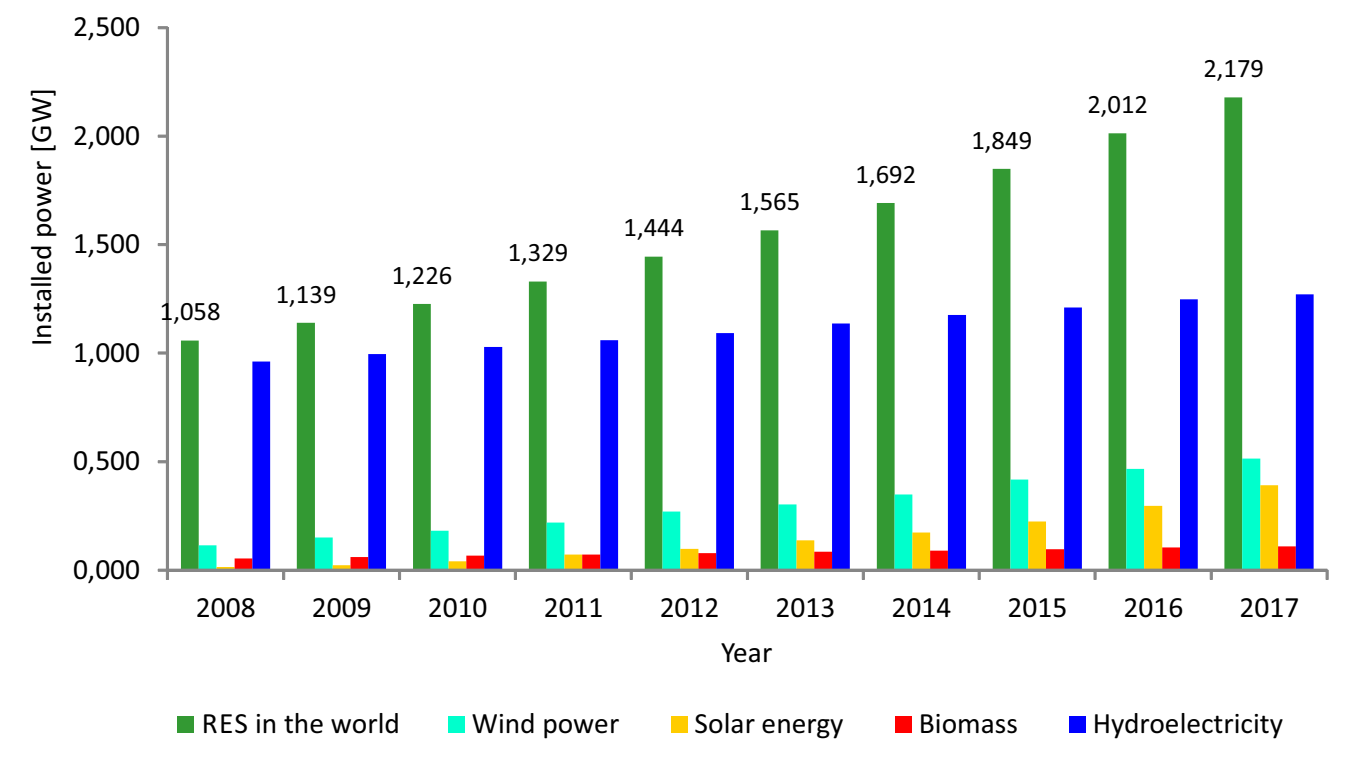

Fig. 1. Installed capacity of individual RES systems worldwide in 2008-2017 (IRENA 2018)

Rys. 1. Moc zainstalowana poszczególnych systemów OZE na świecie w latach 2008-2017

ses equipment efficiency and lowers production costs. In general, we can obtain solar energy, geothermal energy and wind energy in residential buildings, as in others. The difference in these systems lies primarily in the size of the installation and the scale of its use. In residential buildings, we can reduce our dependence on external energy supplies to a significant degree, and often to a total extent. In designing renewable energy systems, we can provide full coverage of the building's energy needs from RES. Such a possibility is most convenient for single-family houses, where the demand for electricity and heat can be fully covered from the RES installation. This means that the cost of electricity and heat consumed by the building will be close to zero. 
Facilities with minimum heat demand are called passive facilities. Such an effect is achievable under the assumption that the building is energy-efficient, which means that it is made of highly thermal insulating materials, where the heat demand is covered from a small heating system, usually in the form of floor heating. Apart from that, heat gains from the installed equipment are used, as well as heat recovery from ventilation (recuperation). Passive buildings, including residential houses, are distinguished by their low energy demand for heating, at the level of less than $15 \mathrm{kWh} /\left(\mathrm{m}^{2}\right.$ year). This means that heating $1 \mathrm{~m}^{2}$ of the house area throughout the year requires energy equal to $15 \mathrm{kWh}$. The idea of passive houses is that the total demand for heat in the house should be satisfied by solar energy, heat recovery from the equipment installed in the house and its occupants.

The structure of energy consumption in households according to the directions of use in 2017 was as follows in Poland (CSO 2019):

$\begin{array}{ll}\uparrow \text { space heating } & -65.8 \%, \\ \uparrow \text { water heating } & -16.3 \%, \\ \uparrow \text { meal preparation } & -8.3 \%, \\ \uparrow \text { lighting, electrical equipment } & -9.6 \% .\end{array}$

According to this summary, $82.1 \%$ of energy demand for households is heat. Electricity is $17.9 \%$ of the total energy needed for the facility. This structure may change if we assume that domestic hot water will be produced using electricity. Some rooms in the facility can also be heated with electricity. Some passive building designs, directly assume heating only with electricity. However, such facilities represent a small fraction of all residential buildings. The presented structure of heat and electricity demand allows assumptions about the installation of appropriate RES systems to cover the heat and electricity demand of the facility to be made. The greatest emphasis should be put on obtaining heat, which can be generated to prepare hot water in solar collectors and heat pumps, which will provide heating to the building. Electricity will be generated mostly in photovoltaic systems, and in situations of high demand, using wind turbines is also proposed. The tendency to use electricity for hot water heating should be mentioned. Then electricity will already represent $34.2 \%$ of the total energy demand of the building. However, one should remember that giving up the use of solar collectors, whose installations are relatively complicated and expensive, will result in the need to use energy storage facilities, which will ensure the continuity of capacity supply to the equipment. The possibility of development of RES systems is conditioned not only by economic and social aspects, but also by technical ones (Szczerbowski and Ceran 2013).

According to data published by GUS, the wind energy sector generated 12.8 TWh of energy in 2018. Due to support programs, a significant increase in installed capacity is observed in photovoltaic systems, which may exceed the estimated values in 2020. Further development trends in new installations of RES systems are closely related to the energy policy of a given country (Szczerbowski 2015). The legal and economic conditions will largely depend on the increase of connection capacities in RES installations. 


\subsection{Photovoltaic installations}

PV photovoltaic installations are currently the most popular RES-related systems in Poland. They owe their great popularity to the beneficial systems supporting the purchase and installation of the entire photovoltaic system. Non-reimbursable grants from government programs and very favorable, low-interest loans prompt potential customers to increasingly decide to install systems generating electricity from solar radiation. Those who are interested in buying PV systems are also convinced by the fact that electricity prices keep increasing and the awareness of the impossibility of stopping further price increases in the future. Another argument justifying the correctness of the PV installation is the increase in efficiency, the capacity of individual PV panels, which translates into higher energy output from the same surfaces. The advanced technology makes temporary inconveniences, such as partial shading, no longer an obstacle in the efficient operation of the entire installation. Previous systems were not resistant to such phenomena and when the PV panel was covered, the entire string stopped generating the energy. Modern Solar-Edge type solutions allow only the obscured part of the PV module surface to be excluded from the operation. Installations equipped with power optimizers provide increased efficiency and reliability of the entire photovoltaic system. They also enable full control of the generated electricity even in individual PV panels. The installed capacity of micro photovoltaic installations in Poland as at December 31, 2019 was 990 MW (URE 2020). An example of a $9.9 \mathrm{~kW}$ photovoltaic installation, which was installed near Poznań, generated a total of $10.77 \mathrm{MWh}$ of electricity in 2019. The entire installation consists of 33 pieces of monocrystalline panels of $300 \mathrm{~W}$ each. Figure 2 shows the energy output of this PV installation in each month of 2019 (green). The generated energy is compared with the monthly energy demand for the common parts of a multi-family building. As the diagram shows, the shortfall of electricity generated from PV panels falls in the winter months. Such a low generation of electricity is unable to cover the energy needs of the building. This happens at a period when the days are the shortest and when electricity is most required. It should be pointed out that an inexpensive and good way of storing electricity is to transfer surplus production to the external power grid. During the periods of increased demand (winter) or at night, when the installation is not operating, we can receive the previously transferred surplus energy. The operator of the energy system reduces the transferred energy value by $20 \%$. This is the case for installations up to $10 \mathrm{~kW}$. In the case of larger installations, we will be able to receive $70 \%$ of the transferred electricity. Both 20 and $30 \%$ represent, in a way, the costs of storing the transferred energy in the grid. The economic aspect, the profitability of installing such an installation is described in point 3 of this article.

The most advantageous solution is the use of an on-grid photovoltaic installation, which will be able to return the surplus energy produced to the power grid. It is sensible to use your energy storage, which will first store the surplus electricity and only after it is fully charged will it transfer energy to the external grid. The correct functioning and proper order of energy transfer should be supervised by automatics, which according to the developed algorithm will manage the flow of the generated electricity. An overview of the operation of an on-grid installation with 


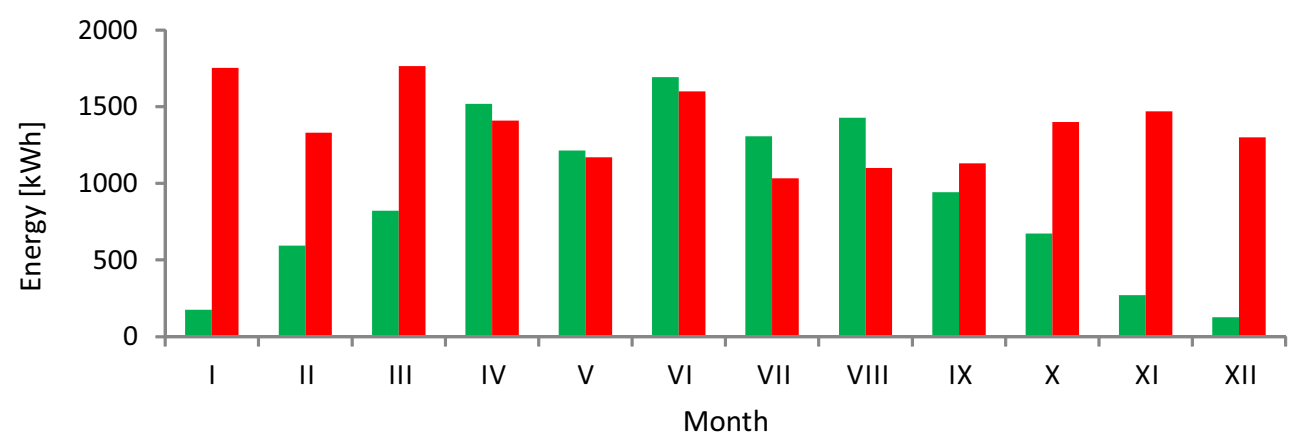

Energy generated in PV $\quad$ Energy demand

Fig. 2. The comparison of the electricity demand in a facility with electricity generation in a $10 \mathrm{~kW}$ PV installation for particular months (own study)

Rys. 2. Zestawienie zapotrzebowania energii elektrycznej w obiekcie z wytwarzaniem energii elektrycznej w instalacji PV $10 \mathrm{~kW}$ dla poszczególnych miesięcy

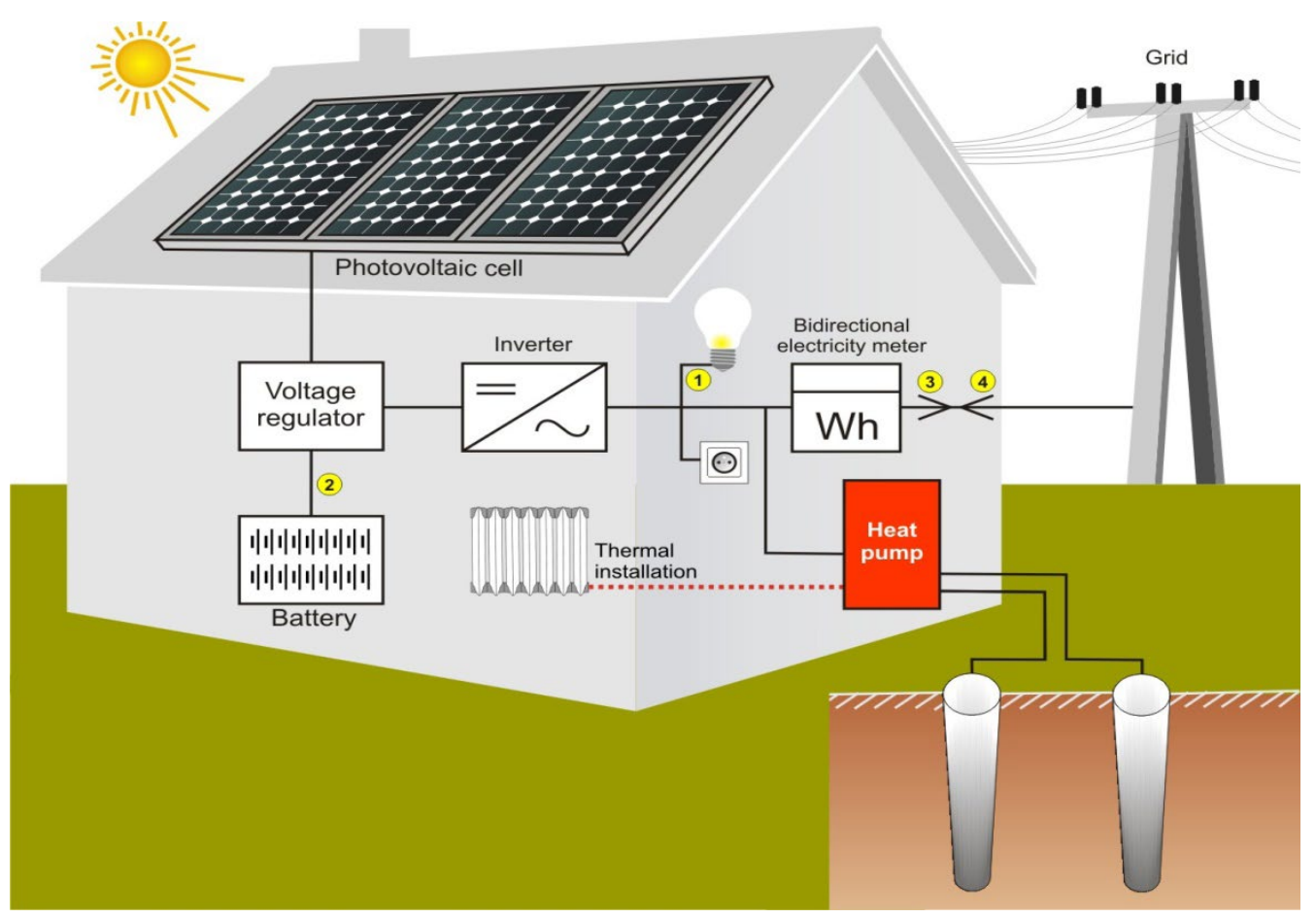

Fig. 3. Schematic diagram of an on-grid photovoltaic installation with energy storage (own study)

Rys. 3. Poglądowy schemat instalacji fotowoltaicznej typu on-grid z magazynem energii 
an energy storage facility is shown in Figure 3. The order of energy transfer to individual circuits is marked with digits. Circuit No. 1 is an internal installation of the facility, which supplies the equipment (e.g. monitoring, circulation pumps of $\mathrm{CH}$ (central heating), DHW (domestic-hot-water), heat pumps, ventilation)) and also the lighting circuits, alarm systems and other energy receivers. Next, the energy is transferred to the energy storage, and finally it is given to power network 3. In case of a lack of current energy generation in PV panels and a lack of stored energy in the battery, the energy will be taken from the external network 4.

\subsection{Heat pump}

After photovoltaic systems, heat pumps are the second most popular systems. The interest is caused by the fact that a significant share of the energy consumption for heating the facility is used. The type of used heat pump determines the location of the object and its immediate surroundings. Recently, the most popular among the customers are air heat pumps, which are relatively simple to install and attractive in terms of price. The only disadvantage is the audible operation of outdoor units. Along with the development of technology, solutions that are characterized by a horizontal operation volume of $35 \mathrm{~dB}$ at a distance of $3 \mathrm{~m}$ were developed. They are more expensive to manufacture and purchase, but are more efficient ground source heat pumps. In this case, heat is not extracted from the air, as in the first-mentioned type, but from the ground. The final choice of the type and cost-effectiveness of a suitable heat pump depends strictly on the specific object, its location, insulation properties and other parameters that are taken into account when calculating and selecting the appropriate type and power of the heat pump system. A simplified operating diagram of the heat pump system is shown in Figure 4. It also shows the estimated energy output. In the case of an air heat pump, a $5 \mathrm{~kW}$ sample power output means $1 \mathrm{~kW}$ of electricity from the grid. The energy of $4 \mathrm{~kW}$ is taken from the air. The ground source heat pump has an average energy yield in the range of $30-50 \mathrm{~W}$ from 1 linear meter of vertical bore. This means that, for example, two boreholes of $100 \mathrm{~m}$ each, will produce $8 \mathrm{~kW}$ of power.

\subsection{Solar collectors}

Systems in which the production of DHW (domestic-hot-water) is carried out for domestic users. These were the first systems using solar energy to cover the energy needs of facilities, in this case in the form of domestic hot water. The relatively complex system of installations consisting of various devices and equipment, as well as the rather high costs of purchase and installation and the lack of continuous, full use of solar energy, caused a decline in popularity 


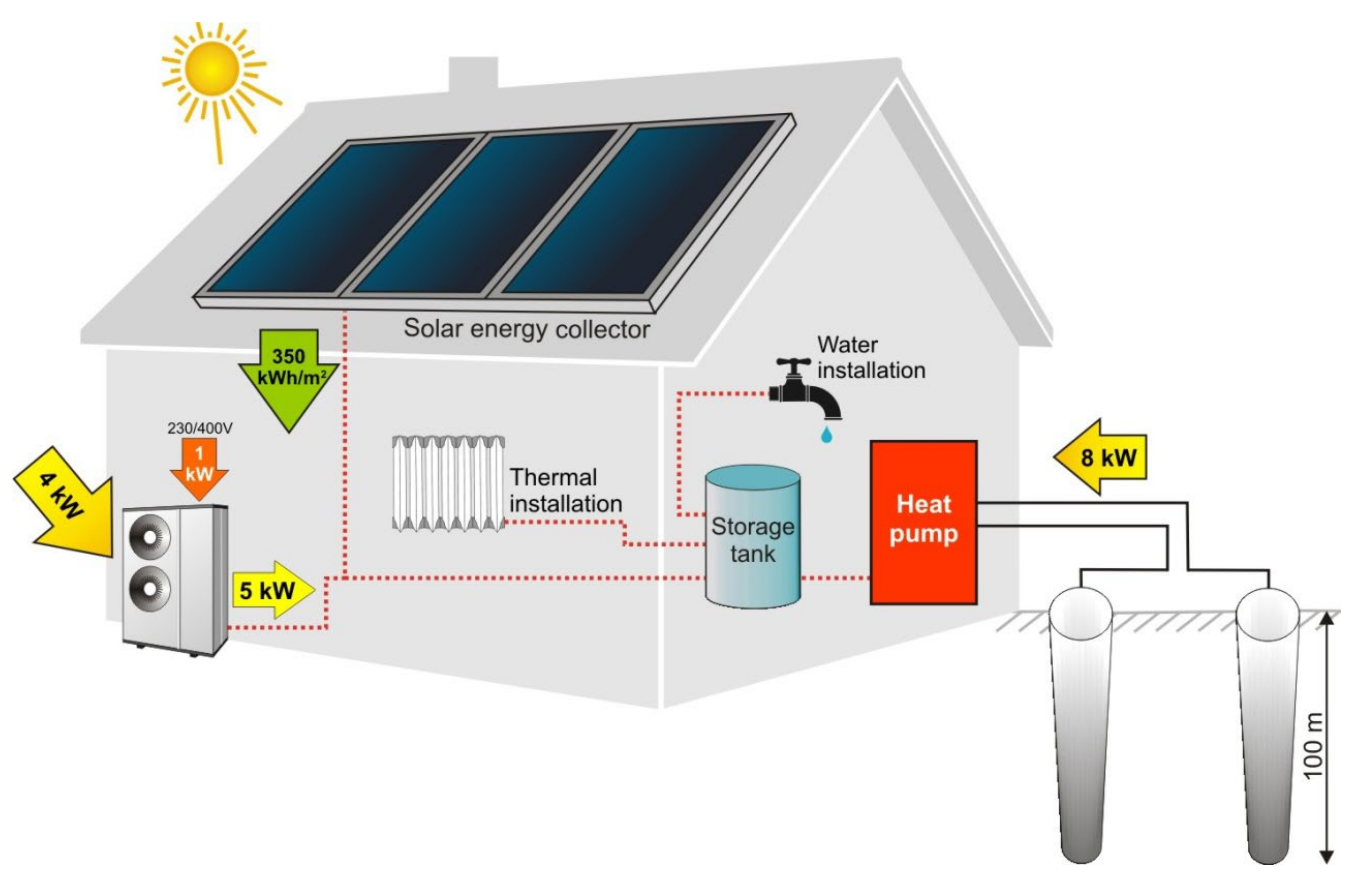

Fig. 4. Pictorial diagram of the heat pump ground and air system (own study)

Rys. 4. Poglądowy schemat instalacji gruntowej i powietrznej pompy ciepła

of these systems. The development of photovoltaic systems that could ensure the production of DHW by heating water with electric heaters caused the companies to withdraw from researches and developing solar collector technology. In Central Europe, on a cloudless summer day we have $5 \mathrm{kWh}$ radiation per $\mathrm{m}^{2}$ of solar collector surface.

Solar collectors can generate $350 \mathrm{kWh}$ of solar energy annually from $1 \mathrm{~m}^{2}$ of absorber area (according to DIN V 18599). Such a value is shown in Figure 4. It is a schematic representation of the installation generating domestic hot water and heating of the facility. In practice, as long as there are no RES installations in the facility, a heat pump is usually used to provide heating and domestic hot water. The economic aspect of the solar installation usage is discussed in point 3 of the article.

\subsection{Wind turbines}

Wind power systems are less predictable than photovoltaic systems. The duration, force and direction of the wind cannot be defined in a simple and obvious way. Data on the wind synergy potential at a given location is collected by measuring masts before large wind farms 
are installed. Measuring usually takes 12 months. However, it is common for the predicted energy carried by the wind to deviate from these estimated values from previous measurements. In RES systems used in residential buildings, wind turbines play the role of an additional, complementary energy generation system. The most commonly used turbines are those of up to 1-10 kW. Generally, no wind yield measurements are made for such devices. Wind turbines are an additional installation for photovoltaic installations. In residential buildings, it is common to use vertical axis turbines, which are relatively easy to install and have a low noise level. Horizontal axis turbines are rarely used and their power does not exceed $1 \mathrm{~kW}$. Low-power wind turbines are a good alternative to larger wind turbines. They can be installed at any location, do not affect the landscape, and if the mast structure does not exceed $3 \mathrm{~m}$ above the building's external outline, they do not require any building permit. The energy they can produce can be simply calculated by multiplying the number of wind hours per year, in a given region, by the average rated output of the turbine.

\subsection{RES hybrid installations}

The high efficiency and continuity of power generation in RES systems are most often hindered by high dependence on prevailing weather conditions. Heat pumps have the greatest predictability of energy production, regardless of whether they are geothermal installations that use Earth's energy or those that generate heat from the air - air heat pumps, e.g. Split type. It is slightly more difficult to determine the amount of energy generated from the Sun, as the availability of solar radiation is strongly dependent on atmospheric conditions. Due to climate changes, the estimation of solar energy generation from the sun, based on archived statistical data, is often mistaken. By implementing RES hybrid systems, we increase the efficiency of generated energy and ensure continuity of energy production as far as possible. It happens when using e.g. wind turbines, which can generate energy at night, when photovoltaic systems do not produce any amount of energy. The hybrid system consisting of a photovoltaic installation, a wind turbine, a heat pump and solar collectors are shown in Figure 5. The PV installation and the wind turbine will generate electricity. The heat pump will produce heat to heat the facility, while the solar collectors will be used to heat domestic hot water in the water system. Hybrid installations are one of the best systems to reduce the demand for conventionally generated energy (Sowa 2018). At the same time, they can be implemented in a way that does not disturb the architecture of the building, which is very important e.g. in the case of historic facilities (Boroń et al. 2016). 


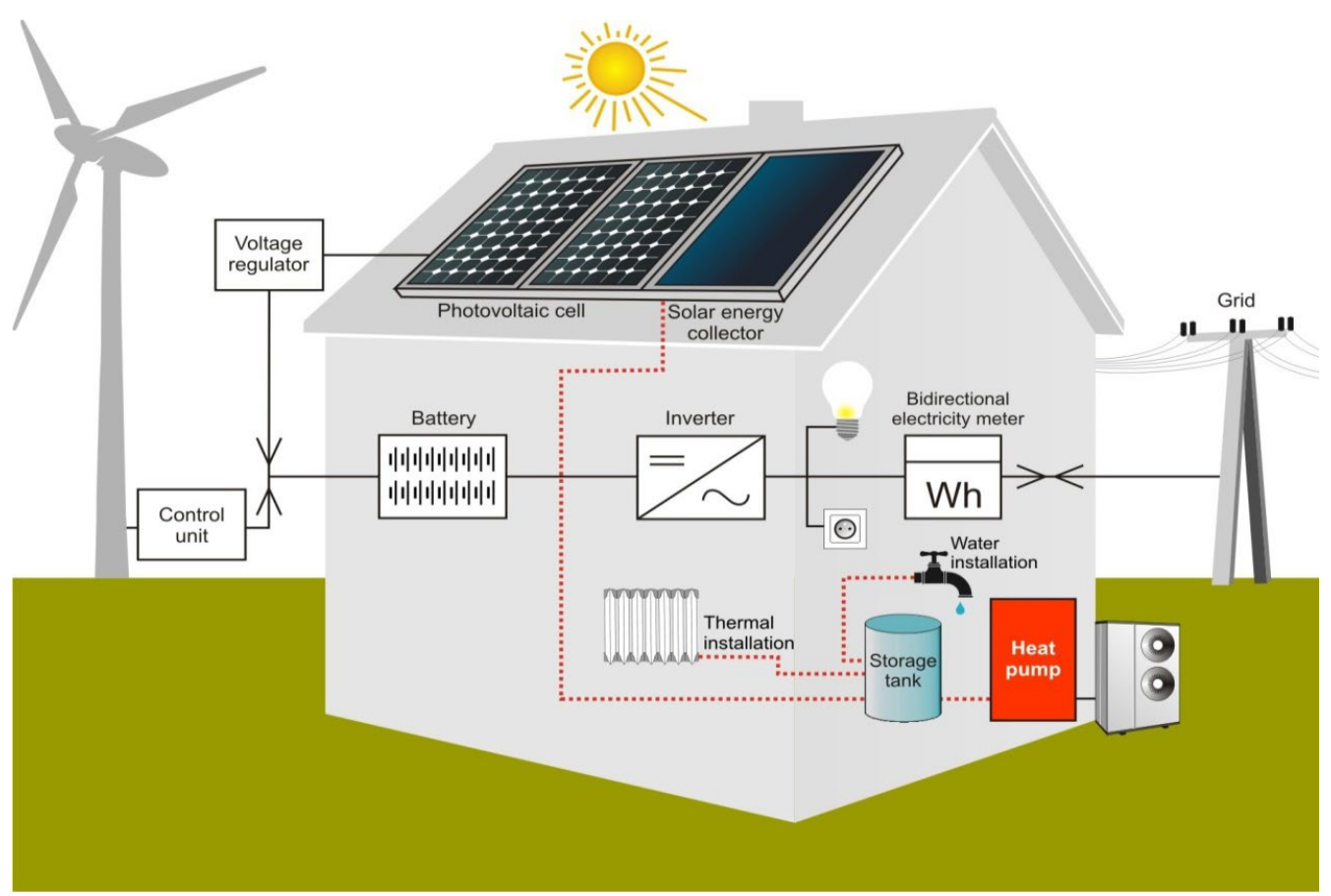

Fig. 5. Pictorial diagram of RES hybrid system (own study)

Rys. 5. Poglądowy schemat instalacji hybrydowej OZE

\section{Energy efficiency of the facilities}

The concept of facility efficiency is a term often used to describe the electricity and heat demand for a facility. The highest possible energy efficiency of buildings is continuously pursued by minimizing heat and electricity losses. There are several measures defined in various laws and directives that lead to improvements in the energy efficiency of facilities (Dołega 2017). The definition of energy efficiency has been set out in the Act of 2016 and is defined as the ratio of the result obtained to the amount of energy used to achieve this effect (UEE 2016). Accordingly, we can define the energy efficiency of a facility as energy efficiency. The energy efficiency parameter will indicate the degree of comfort when using the facility, with a maximum reduction of electricity and heat consumption at the same time.

The drive to improve the energy efficiency of facilities is primarily an opportunity to reduce the cost of electricity and heat supplied to the facility. Consequently, it is also a pro-environmental measure, aimed at reducing the consumption of fossil fuels, which are mostly used for system production of electricity and heat. 


\subsection{Legal requirements}

The energy efficiency of facilities means also certain requirements which are included in EU directives and Polish law regulations. The European Parliament's 2012 directive imposes an obligation on member states to take appropriate measures to improve the energy efficiency of facilities, e.g. to reduce final energy consumption by 1\% per year (DPE 2012).

This is the main document related to energy efficiency, which replaced the earlier Directive 2006/32/EC of the European Parliament and of the Council from April 5, 2006. In 2015, the European Union Commission's statement was issued, which defined the European Union strategy in the field of heating and cooling (CKE 2016).

The Polish legislation has created provisions for carrying out energy audits of facilities to analyze the energy consumption and to determine the technical condition of the facility, its installation (UEE 2016). The earlier Act of 2014 concerns the energy performance of facilities. It mainly concerns the rules of preparing the Energy Performance Certificates for facilities as well as the rules of inspection of the heating and air-conditioning system (UCEB 2014). The aim of all directives, laws and other regulations in the field of energy efficiency is to reduce the consumption of primary energy and to introduce conditions that will support the introduction of solutions to reduce energy consumption both in companies, factories and public buildings. The energy efficiency of buildings is primarily a possibility to reduce the cost of electricity and heat supplied to the facility. Consequently, it is also a pro-environmental measure, aimed at reducing the consumption of fossil fuels, which are mostly used for the systemic production of heat and electricity.

\subsection{Possible ways to increase energy efficiency}

We can also improve the energy efficiency of facilities by implementing renewable energy systems. The RES systems presented in the article allow to significantly reduce energy consumption from external suppliers, which results directly in lower bills for electricity and heat. The improvement of the energy efficiency of facilities can be also obtained by limiting losses and reducing heat consumption in the facility. The basic activities in this area come down to the thermal insulation of external walls, ceilings, roofs and replacement, sealing of door and window joinery, as well as the removal of thermal bridges or other leaks in the facility. The above-mentioned measures are fundamental and most popular in terms of reducing heat consumption in the facilities. In the residential building sector, where the heating systems are old, the modernization of $\mathrm{CH}$ systems is carried out by replacing the boiler and exchanging the radiators and piping. An important measure to improve energy efficiency is the use of automatic temperature control (Shkarovskiy and Gawin 2017). Such actions reduce the demand for fuels and have a beneficial effect on the environment by reducing the emission of $\mathrm{CO}_{2}$ and other pollutants from heating 
boilers. Moreover, the systems of non-refundable subsidies and favorable loans increase interest in the modernization of heating systems.

The improvement of the energy efficiency of a facility in terms of electrical installations most often boils down to the replacement of lighting sources with energy-efficient ones, e.g. LED type, as well as the use of energy-efficient RTV/AGD devices and other energy receivers. Another solution is to reduce electricity consumption by using lighting control systems (Sowa 2019). It is also possible to improve energy efficiency through lower energy charges, e.g. by changing the tariff. According to studies, the use of daylight for room lighting significantly reduces the electricity consumption of lighting installations (Sowa 2019). Measurable gains can be achieved in this case through lighting control with automatic controls, which, based on the room's lighting intensity data, controls and regulates the power of individual luminaires accordingly.

\section{Economic aspect of the RES installations' use}

Each project is evaluated in terms of its cost-effectiveness. Again, this is important for the installation of renewable energy systems. However, considering the RES installation only from a financial point of view is incorrect. The generation of energy, including heat, from renewable sources, is characterized by nearly zero emission of hazardous substances and protects the environment in a significant way, preventing its pollution, e.g. by the absence of harmful $\mathrm{CO}_{2}$ emissions. Although it is possible to predict the amount of energy produced from RES in building installations, it is impossible to predict price changes in the energy market. Accordingly, we can assume that the calculations of payback time of incurred investments are pessimistic versions. Further increases in electricity prices and heat costs will only shorten the payback times and make it more profitable to install these systems. The increase in the share of distributed generation of RES systems is also dictated by economic aspects (Szczerbowski 2011). Small and micro installations are less expensive, easier to install and can be adapted exactly to the needs and requirements of the facility user. The most common configuration would be the implementation of RES systems, producing heat for residential buildings, heat for heating the facility, heat for DHW and electricity. In this case, it was assumed that a photovoltaic installation for the production of electricity and a heat pump for the production of heat for the heating of the building and the provision of domestic hot water will be used. To simulate the calculations, the following object parameters were assumed:

$\checkmark$ usable area of the facility: $120 \mathrm{~m}^{2}$,

$\checkmark$ number of inhabitants: 4 ,

$\checkmark$ climate zone: II,

$\checkmark$ rooms set temperature: $20^{\circ} \mathrm{C}$,

$\checkmark$ DHW temperature: $50^{\circ} \mathrm{C}$. 
For such an object the demand for DHW will be $50 \mathrm{dm}^{3} \cdot 4=200 \mathrm{dm}^{3} /$ day.

Heat demand of the building $-6 \mathrm{~kW}$ (according to the PN-EN 12831 standard). To obtain this amount of heat, it is necessary to make vertical boreholes in the ground with a total length of about $130 \mathrm{~m}$ or use a horizontal ground collector of $280 \mathrm{~m}^{2}$. The total heat demand of the building will be $8,893 \mathrm{kWh}$ for heating the object and 3,363 kWh for DHW, i.e. 12,256 kWh in total. To obtain this amount of heat, the heat pump will consume a total of $2,886 \mathrm{kWh}$ of electricity for its operation. The most reasonable will be the use of an air-to-water heat pump. Table 2 below shows the data for the Vitocal 200-S AWB-M-E(-AC) 201.D06.

TABLE 2. Average return time of individual RES installations

TABELA 2. Średni czas zwrotu poszczególnych instalacji OZE

\begin{tabular}{|l|c|c|c|c|}
\hline \multicolumn{1}{|c|}{ Specification } & $\begin{array}{c}\text { Heat pump } \\
6 \mathrm{~kW}\end{array}$ & $\begin{array}{c}\text { Solar system } \\
5 \mathrm{~m}^{2}\end{array}$ & $\begin{array}{c}\text { PV system } \\
10 \mathrm{~kW}\end{array}$ & Gas system \\
\hline Generated energy [kWh/year] & 6,294 & 1,750 & 10,770 & 6,294 \\
\hline Electricity consumption [kWh] & 2,886 & 130 & - & \\
\hline Cost of energy consumed [PLN/year] & 1,732 & 67 & - & $969+605$ \\
\hline Annual profit [PLN] & 1,607 & 1,467 & 5,720 & - \\
\hline Installation cost [PLN] & 28,000 & 11,000 & 45,000 & 3,700 \\
\hline Payback time [years] & $9-15$ & $7-8$ & 8 & - \\
\hline
\end{tabular}

Source: own study.

Table 2 presents the time after which the expenses incurred for individual installations will be returned to the investor. The presented estimated calculation of payback time assumes the cost of $1 \mathrm{kWh}$ at the level of PLN 0.55 . The payback time, defined in years, was calculated as the ratio of the expenditure incurred for the purchase and installation of the installation to the average annual investment revenue. These are estimates, as the precise calculation of the payback time depends on many factors, i.e. exact location of the installation, type and type of individual system components used, proper selection of components and correct execution of the installation. The most difficult to estimate are the heat pump installations whose payback time is correlated with the specific parameters of the facility and its location. Variations in the payback time for heat pump investments result from different heat acquisition systems (ground, air) as well as the type of used heat pump, the size of the system and additional elements necessary to be installed in the heating system.

Electricity from renewable energy systems used in facilities is produced in photovoltaic panels. The $10 \mathrm{~kW} \mathrm{PV}$ installation presented in point 1.3 of this article allows us to generate 10.77 MWh of energy per year. The cost of installing such a system should be fully recovered after about 8 years. Figure 2 shows a diagram of the amount of energy obtained from a $10 \mathrm{~kW} \mathrm{PV}$ installation and the energy demand in each month. As mentioned in point 1.1 (Fig. 2), the chart shows the electricity consumption (red) for the common parts of a multi-family residential building with 30 units). Electricity is consumed in the common areas, i.e. lighting of the underground 
garage, staircase, corridors and external elevation. According to the diagram, the described PV installation is not able to cover the annual electricity demand in this facility. Between April and August, the photovoltaic installation produces enough energy, while in the rest of the months it does not cover the energy demand. The surpluses occurring in the summer months will not cover the shortage during the winter. It can be concluded that the use of the presented PV installation in this facility only reduces electricity costs.

As it was already mentioned, for a solar collector, we assume an annual solar heat yield of $350 \mathrm{kWh} / \mathrm{m}^{2}$. Table 2 presents the data on the solar system consisting of two Vitosol 100-FM flat-plate collectors installed in the vicinity of Poznan. The total area of the collectors is $5 \mathrm{~m}^{2}$. The energy consumption of a solar collector system is limited to the operation of circulation pumps and control and measurement automation. Once the financial outlay on the installation is recovered, it will also include the type of collectors used and their types. Vacuum collectors are more efficient but more expensive. The last column of Table 2 shows data on the use of the gas installation as a reference for the submitted RES installations.

The data presented is for a gas-fired condensing boiler. In determining the costs of gas heating, assumed value was PLN 0.12/1 kWh of thermal energy and PLN 605 per year of fixed charges for the natural gas supplier.

\section{Summary}

The number of RES installations in residential buildings is constantly increasing. Due to the energy needs of facilities, photovoltaic installations and heat pumps are becoming more and more popular. In Poland, among others, thanks to governmental and local government support programs, in 2019 the installed capacity in photovoltaics increased by $163.8 \%$ compared to the previous year. This means that as of December 1, 2019, the installed capacity in photovoltaics in the NPS (National Power System) was 1,185.7 MW. The implementation of RES systems in residential buildings allows for measurable savings in electricity and heat charges. Moreover, it allows the natural environment to be protected by limiting the heat and electricity consumption from external suppliers, who deliver energy generated mostly from conventional sources.

Analyzing the functioning of renewable energy systems, it is difficult to notice the disadvantages of such systems. Well-designed and constructed RES installations should function efficiently and without any failures for many years, having a positive impact on the environment and increasing the energy efficiency of facilities. The presented examples show that the cost of micro installation of RES installations pays for itself within 7 to 15 years, depending on the type of system and technology used. After this period, renewable energy installations will bring measurable financial profits. The awareness of beneficial environmental impact, thanks to the reduction of energy consumption generated mostly in conventional power plants and heating plants, is a factor determining the validity and profitability of RES installations. 
Observing a steady and dynamic increase in the share of renewable energy sources in the energy system, it is likely that the current trends will continue. The condition is to maintain and develop the national renewable energy support system. The highest growth in Poland was recorded for installations using solar radiation energy. The total amount of electricity introduced by micro-installations into the distribution network in 2019 was 47,896.048 MWh (URE 2020). If such an upward trend is maintained, a record may be recorded in the coming years in the connected capacity from renewable energy sources. Micro and small RES installations will also play an important role here.

\section{References}

Boroń et al. 2016 - Boroń, W., Chомiaк, A. and SmyŁA, J. 2016. Hybrid Installation Using Renewable Energy Sources to improve Energy Efficiency of Historic Buildings (Hybrydowa instalacja wykorzystująca OZE do poprawy efektywności energetycznej budynków zabytkowych). Ciepłownictwo, Ogrzewnictwo, Wentylacja Vol. 47, Iss. 4, pp.146-151 (in Polish).

CKE 2016. EU Commission Communication COM(2016)0051. EU strategy on heating and cooling from 16.02.2016. Brussels 2016.

DolęGA, W. 2017. Selected aspects of energy efficiency (Wybrane aspekty efektywności energetycznej). Polityka Energetyczna - Energy Policy Journal Vol. 20, Iss. 4, pp. 67-78 (in Polish).

DPE 2012. Directive 2012/27/EU of the European Parliament and of the Council of 25 October 2012 on energy efficiency. Brussels 2012.

GUS 2019a. Efficiency of energy use in the years 2007-2017, Information and statistical studies, GUS (Efektywność wykorzystania energii w latach 2007-2017, Informacje i opracowania statystyczne, GUS). Warszawa 2019 (in Polish).

GUS 2019b. Energy from renewable sources in 2018, GUS (Energia ze źródet odnawialnych w 2018 roku, GUS). Warszawa 18.11.2019 (in Polish).

IRENA 2015. International Renewable Energy Agency. REmap 2030: Renewable Energy Prospects for Poland (Perspektywy energetyki odnawialnej dla Polski). Abu Dhabi, United Arab Emirates (in Polish).

IRENA 2018. International Renewable Energy Agency. RENEWABLE CAPACITY STATISTICS 2018 (Statystyka zdolności wytwórczych). Abu Dhabi, United Arab Emirates (in Polish).

LeŚNY et al. 2018 - LeŚNY, J., PANFIL, M. and URBANIAK, M. 2018. Influence of irradiance and irradiation on characteristic parameters for a solar air collector prototype. Solar Energy Vol. 164, pp. 224-230.

ShKarovskiy, A. and Gawin, R. 2017. Improving energy efficiency of public buildings (Poprawa efektywności energetycznej budynków użyteczności publicznej). Polityka Energetyczna - Energy Policy Journal Vol. 16, Iss. 1, pp. 5-15 (in Polish).

SiedleCKA, A. and GrąSzKo, B. 2016. Renewable energy sources as a tool to influence the quality of life of households (Odnawialne źródła energii jako narzędzie oddziaływania na jakość życia gospodarstw domowych). Stowarzyszenie Ekonomistów Rolnictwa i Agrobiznesu. Roczniki Naukowe Vol. XVIII, Iss. 22 (in Polish).

Sowa, S. 2018a. Improving the energy efficiency of lighting systems by the use of solar radiation. E3S Web of Conferences Vol. 70, DOI: 10.1051/e3sconf/20187001013, EDP Sciences 2018.

SowA, S. 2018b. Increasing the energy efficiency of hybrid RES installations using KNX system. Renewable Energy Sources: Engineering, Technology, Innovation, Springer, pp. 387-394.

Sowa, S. 2019. Lighting control systems using daylight to optimize the energy efficiency of the building. Progress in Applied Electrical Engineering (PAEE), DOI: 10.1109/PAEE.2019.8788991, pp. 1-4. 
Szczerbowski, R. 2011. Decentralized Energy Generation and Smart Grid - Virtual Power Plant (Generacja rozproszona oraz sieci Smart Grid - wirtualne elektrownie). Polityka Energetyczna - Energy Policy Journal Vol. 14, Iss. 2, pp. 391-404 (in Polish).

SzCZERbowski, R. 2015. Selected European countries energy policy and the Polish energy strategy (Polityka energetyczna wybranych krajów europejskich a strategia energetyczna Polski). Polityka Energetyczna - Energy Policy Journal Vol. 18, Iss. 3, pp. 5-15 (in Polish).

SzCZERBowski, R. and Ceran, B. 2013. Small scale, distributed power generation based on renewable energy sources - possibilities for development, cost of electricity production, and technical problems (Możliwości rozwoju i problemy techniczne małej generacji rozproszonej opartej na odnawialnych źródłach energii). Polityka Energetyczna - Energy Policy Journal Vol. 16, Iss. 3, pp. 193-205 (in Polish).

UCEB 2014. Act on the energy performance of facilities 2014 item 1200 of 29.08.2014 (Ustawa o charakterystyce energetycznej budynków Dz.U. 2014, poz. 1200 z dn 29.08.2014 r.). Warszawa (in Polish).

UEE 2016. Act on the energy performance of the facilities 3, Journal of Laws of the Republic of Poland from 20.05.2016 (Ustawa o efektywności energetycznej, art. 2, pkt. 3, Dziennik Ustaw RP z dn. 20.05.2016 r.). Warszawa (in Polish).

UOZE 2015. Act on Renewable Energy Sources, Journal of Laws of the Republic of Poland from 20.02.2015 item 478 (Ustawa o odnawialnych źródłach energii, Dziennik Ustaw RP z dn. 20.02.2015 r., poz. 478). Warszawa (in Polish).

URE 2020. URE Report, Collective information on electricity generation from renewable energy sources in a microinstallation and introduced into the distribution network in 2019 (Raport URE, Zbiorcze informacje dotyczace energii elektrycznej wytworzonej z odnawialnego źródła energii w mikroinstalacji i wprowadzonej do sieci dystrybucyjnej w 2019 r.). Warszawa (in Polish).

Sławomir SowA

\title{
Implementacja systemów energetyki odnawialnej sposobem na poprawę efektywności energetycznej budynków mieszkalnych
}

\author{
Streszczenie
}

Nieustający wzrost popularności systemów odnawialnych źródeł energii sprawia, że użytkownicy obiektów mieszkalnych coraz częściej stosują rozwiązania prowadzące do dywersyfikacji dostaw energii. Zastosowanie systemów OZE w obiektach mieszkalnych przyczynia się nie tylko do większej dbałości o środowisko naturalne, ale w wymierny i znaczny sposób poprawia efektywność energetyczną obiektu. Decydując się na zastosowanie układów hybrydowych, można ograniczyć lub całkowicie wyeliminować dostawy z konwencjonalnych źródeł energii. W artykule opisano typowe układy systemów energetyki odnawialnej, które z powodzeniem są wykorzystywane w budynkach mieszkalnych. Wykazano także wpływ ich zastosowania na wielkość uzyskanych oszczędności w zużyciu energii z zewnętrznych z konwencjonalnych źródeł. W budynkach mieszkalnych możliwość wytwarzania energii w postaci prądu i ciepła jest uzależniona od wielu czynników, które determinują rodzaj i wielkość zastosowanych systemów pozyskiwania 
energii ze źródeł odnawialnych. Wielkość udziału wytwarzanej energii z OZE w budynkach mieszkalnych jest uzależniona od lokalizacji obiektu, jego architektury, zamożności właścicieli oraz systemów wsparcia finansowego, które oferują instytucje samorządowe i państwowe.

Należy zakładać dalszy i ciągły rozwój OZE, który przyczyni się do zwiększenia udziału wytwarzanej energii elektrycznej i ciepła w gospodarstwach domowych. Rozwój technologii, spadek cen urządzeń i elementów używanych do instalacji układów wytwarzających zieloną energię, będzie sprzyjającym czynnikiem wzrostu popularności systemów OZE, nie tylko dla obiektów mieszkalnych, ale także innego rodzaju obiektów.

W artykule opisano popularne systemy energetyki odnawialnej stosowane w obiektach. Zwrócono także uwagę na aspekt ekonomiczny dotyczący zastosowania systemów OZE. Przedstawiono pozytywne oddziaływanie instalacji OZE na środowisko oraz oszacowano średni czas zwrotu poniesionych nakładów finansowych. Przeprowadzona analiza ekonomiczna ma charakter poglądowy i dotyczy poszczególnych układów systemów energetyki odnawialnej stosowanych w budownictwie mieszkalnym.

SŁowA KLUCZOWE: efektywność energetyczna, oszczędność energii, instalacje OZE 
